\title{
DIGITALNE RAZLIKE IN E-IZOBRAŽEVANJE
}

\section{POVZETEK}

Informacijske in komunikacijske tehnologije (IKT) se z namenom razširitve dostopa do izobraževanja odraslih lahko uporabljajo na mnoge načine. IKT, zlasti internet, spreminja vse vidike življenja in delovanja sodobne družbe. Spletno učenje $v$ razvitem svetu se širi in postaja vse pomembnejša oblika poučevanja in učenja, vendar je uporaba IKT $v$ učnem procesu večinoma delna in nepovezana. Kvalitativne spremembe v uporabi IKT v izobraževanju (z integracijo računalniško podprtih oblik komunikacije in interakcije ter informacijskih virov zunaj tradicionalnega izobraževalnega okolja) še niso bile v celoti dosežene. E-izobraževanje zunaj formalnih okoliščin je pogosto povezano z izboljšanjem pismenosti odraslih in osnovnega izobraževanja. Nova tehnologija se lahko uporabi za številne izobraževalne programe za odrasle, ki se izobraževanja sicer ne morejo udeležiti, lahko pa je tudi pomembno orodje informiranja in svetovanja. Izobraževalce odraslih na tem področju čakajo še mnogi izzivi, npr. kako razširiti dostop do IKT na podeželju in manj razvitih območjih, kako izboljšati digitalne kompetence in kako oblikovati e-učenje, ki bo dostopno vsem udeležencem.

Ključne besede: e-izobraževanje, izobraževanje odraslih, izobraževanje na daljavo, dostopnost, uporabnost, e-gradiva, digitalne razlike

\section{DIGITAL DIVIDE AND E-EDUCATION-ABSTRACT}

The use of Information and Communication Technologies (ICTs) in widening access to adult learning in many directions. ICT, especially the Internet, is changing all aspects of life and functioning of the modern society. Online learning is expanding in the developed world and becoming an increasingly important way of teaching and learning. Nevertheless, the use of ICT in the learning processes is mostly still partial and incoherent. Qualitative changes in this domain (integration of the ICT-based forms of communication and interaction, and information sources outside the traditional educational environment) have not yet been made. E-learning outside formal settings is mostly aimed at improving adult literacy and basic education. The new technology can make many learning programs accessible to the adults without direct access to education and can also become an important basis for provision of information guidance and counseling. Here, adult educators are still faced with several challenges, for instance, how to widen access to ICT in rural and less developed areas, how to improve digital skills and how to make e-learning more accessible to all learners.

Keywords: e-learning, distance education, adult education, accessibility, usability, e-content, digital divide

UDK: 374.74

\section{UVOD}

Razvoj novih spletnih tehnologij običajno spremljata obljuba in upanje, da bodo ti novi mediji povečali dostop do učenja in omogočili vsem odraslim enakopravno sodelovanje v izobraževanju. Med pomembnejšimi dokumenti, ki so poudarjali vlogo novih učnih tehnologij pri povečevanju dostopnosti izobraževanja za vse odrasle, je tudi Hamburška deklaracija o učenju odraslih (Unesco, 1997). V njej poudarjajo, da se bo dostopnost izobraževanja povečala $\mathrm{s}$ »presojanjem razvoja in širjenjem nove tehnologije $z$ regionalnega, lokalnega in kulturnega zornega kota, ob upoštevanju opreme, ki je na voljo, in tega, da je infrastruktura nesorazmerno razvita«, in $\mathrm{z}$ »zagotavljanjem enakega dostopa do sistemov odprtega učenja in učenja na daljavo, javnih občil, novih informacijskih in komunikacijskih tehnologij ter z uporabo novih tehnologij pri proučevanju alternativnih poti učenja« (prav tam: 33-34).
Doc. dr. Marko Radovan

Filozofska fakulteta

Univerze $v$

Ljubljani

lzr. prof. $d r$. Dejan Dinevski

Pedagoška fakulteta Univerze $v$

Mariboru 
Koliko so bili ti optimistični cilji doseženi? Ali je razvoj digitalnih tehnologij izpolnil pričakovanja izobraževalcev odraslih? Mnenja o tem so lahko različna. Vsekakor smo danes priče hitremu razvoju digitalnih tehnologij in možnosti, ki jih slednje ponujajo, postajajo vse pomembnejši del našega vsakdanjega življenja in tudi pomembno orodje e-izobraževanja. V članku bomo prikazali tri vidike (ovire), ki lahko zavirajo uresničitev omenjenih ciljev.

Informacijsko-komunikacijske tehnologije (IKT) spreminjajo način, na katerega se učimo (kdaj, kje in kako), ter omogočajo večjo demokratičnost in dostopnost učnih vsebin posameznikom, ki se želijo učiti. Uporaba IKT za razširjanje dostopa do izobraževanja odraslih se je razvila v mnogih smereh. IKT, zlasti internet, spreminja vse vidike življenja in delovanja sodobne družbe. Spletno učenje $\mathrm{v}$ razvitem svetu se širi in postaja vse bolj pomemben način poučevanja in učenja, vendar je v mnogih primerih uporaba IKT v učnem procesu nepopolna in neskladna s potrebami učnega procesa. Spletna gradiva lahko spodbujajo tudi politični in socialni dialog; tako postajajo orodje, s katerim se lahko opolnomočijo skupine ljudi, ki so bile prej prezrte.

Kljub vsem možnostim, ki jih dajejo spletne tehnologije, pa je situacija vse prej kot bleščeča. Če želimo doseči cilje, navedene v Hamburški deklaraciji, ne smemo pozabiti, da mora imeti udeleženec najprej dostop do teh orodij in da se jih mora potem še naučiti uporabljati. V tem smislu so lahko nove digitalne tehnologije vir novih neenakosti in marginalizacije nekaterih družbenih skupin. Napredek v zahodnih družbah v zvezi s tem je bil ogromen, drugod po svetu pa zelo zmeren. Širitev dostopa do učenja ali izobraževanja in splošno udeležbo v družbi prek novih medijev in spletnih tehnologij je mogoče uresničiti le s široko uveljavitvijo spletnih naprav (tra- dicionalnih in mobilnih). Kot lahko vidimo iz Grafikona 1, bo ta cilj težko doseči, saj le manjši del svetovnega prebivalstva uporablja internetne storitve in ima dostop do spleta.

Grafikon 1: Uporaba interneta po geografskih regijah $\checkmark$ letu 2011 (\% prebivalstva)

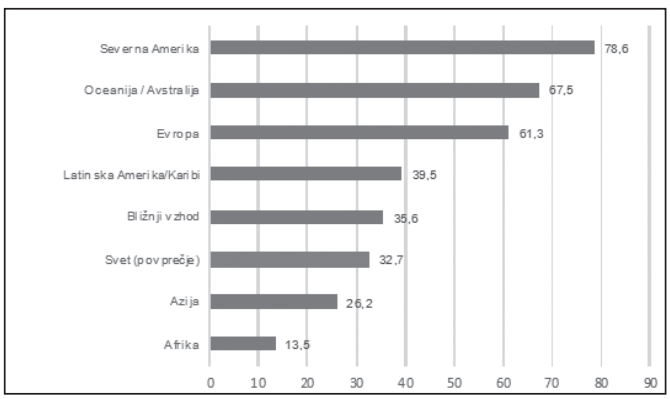

Vir: Internet World Stats, http://www.internetworldstats.com/stats.htm.

V različnih raziskavah ugotavljajo, da v povprečju samo ena tretjina svetovnega prebivalstva uporablja internet in da večina uporabnikov interneta prihaja iz zahodnega sveta: Severne Amerike, Avstralije in Evrope. Dostop do spletnih storitev v svetu se je seveda v minulih letih izboljšal, vendar pa je razhajanje med različnimi deli še vedno ogromno. V zadnjih petih letih so države v razvoju svoj delež glede na svetovno populacijo uporabnikov interneta povečale s 44 odstotkov (leto 2006) na 62 odstotkov (leto 2011). Danes je najhitreje rastoča skupina uporabnikov interneta iz Kitajske in pomeni skoraj 25 odstotkov vseh svetovnih uporabnikov interneta in 37 odstotkov, če jih primerjamo z državami v razvoju

Še bolj skrb zbujajoča pa je razlika med uporabniki svetovnega spleta, ki izhaja iz demografskih značilnosti prebivalstva. Mednarodna telekomunikacijska zveza (angl. International Telecommunication Union) v svojem poročilu iz leta 2011 navaja, da je bilo v letu 2011 v povprečju 45 odstotkov svetovnih 
internetnih uporabnikov mlajših od 25 let (Grafikon 2).

Grafikon 2: Uporabniki interneta po starosti in stopnji razvoja, 2011 *

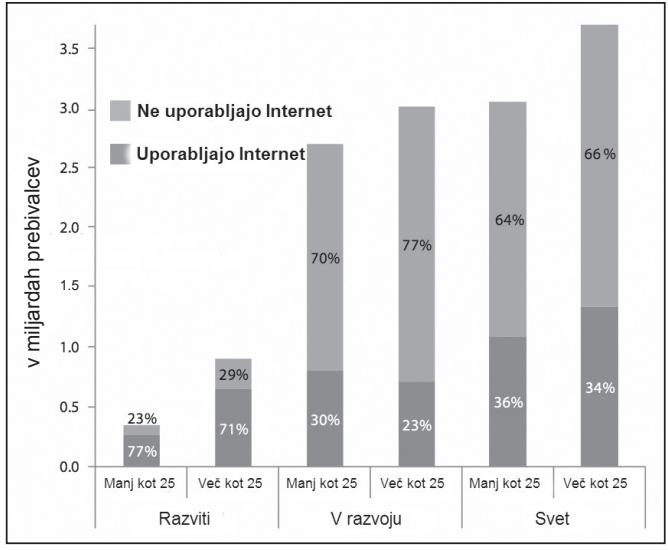

Opomba: * ocena

Ta skupina prebivalstva je najbolj deprivilegirana v državah v razvoju - 70 odstotkov mlajših od 25 let ne uporablja interneta $\mathrm{v}$ primerjavi s 23 odstotki prebivalstva $\mathrm{v}$ isti starostni kategoriji v razvitih državah. Ta delež bi se močno povečal, če bi se $\mathrm{v}$ državah $\mathrm{v}$ razvoju povečal vpis v šole, in seveda $z$ boljšo opremljenostjo šol z IKT. OECD (2001) je na začetku tisočletja uvidel problem digitalnih razlik na področju učenja in prepoznal IKT kot potencialnega spodbujevalca učenja po vsem svetu, vendar pa hkrati kot tveganje, da bi se z uporabo IKT socialne razlike med posameznimi deli sveta in v družbi še dodatno povečale. Temu se brez državnega (političnega) posredovanja najbrž ne bomo mogli izogniti.

\section{RAZLIČNE DIMENZIJE DIGITALNIH RAZLIK}

E. Hayes (2007) poudarja, da je splošno znano, da so tisti, ki nimajo dostopa do digitalnih tehnologij (računalniki, internet), v »informa- cijski dobi« v vedno bolj neugodnem položaju. Castells opredeljuje digitalne razlike kot $\gg$ neenakost dostopa do interneta « (Castells, 2002: 248). Ta dostop naj bi bil prvi pogoj za preseganje neenakosti v družbi, za katero je značilno, da se vse bolj organizira in deluje prek interneta (Castells, 2002). Digitalne razlike podobno opredeljuje Van Dijk (2006), ki jih razume kot »vrzel med tistimi, ki imajo, in tistimi, ki nimajo dostopa do računalnikov in interneta « (prav tam: 178). Digitalne razlike so večinoma povezane s slabim gospodarskim stanjem, nizko stopnjo izobrazbe in drugimi socialnimi kazalniki, ki so značilni za socialno marginaliziranost. Socialne ovire se razumejo kot vzrok, pa tudi kot posledica digitalne nepismenosti.

Van Dijk in Hacker (2003) trdita, da obstajajo štiri vrste ovir za dostop do IKT:

- pomanjkanje kakršnihkoli digitalnih izkušenj zaradi strahu pred računalnikom in nezanimanja za nove tehnologije;

- nemožnost pridobiti računalnik in omrežno povezavo;

- pomanjkanje digitalnih spretnosti, kar je posledica pomanjkljive uporabe in neustrezne izobrazbe ali družbene podpore;

- $\quad$ premalo možnosti uporabe.

Van Dijk (2006) ugotavlja, da so se digitalne razlike pri fizičnem dostopu do računalnikov in interneta $v$ razvitih državah zelo zmanjšale, v nerazvitih družbah pa se še vedno povečujejo. Kar zadeva raven usposobljenosti za uporabo digitalnih tehnologij, pa se digitalne razlike še bolj krepijo. Avtor je prepričan, da so »informacijske spretnosti « (ki so potrebne za dostop z izbiro in obdelavo informacij na računalniku in internetu) in »strateške sposobnosti (sposobnost za uporabo teh sredstev za doseganje posameznikovih individualnih ciljev), ki omogočajo kakovostno uporabo digitalnih tehnologij, zelo neenakomerno porazdeljene med prebivalstvom (prav tam). 
Ta težnja velja tako za razvite, še bolj pa za nerazvite države.

Nekateri drugi raziskovalci tudi opozarjajo, da ni pomembno proučevati samo dostop do digitalnih tehnologij, prav tako pomemben je način, kako te tehnologije uporabljamo. Tudi način uporabe namreč lahko postane dejavnik družbene neenakosti (Mossberger, Tolbert in Stansbury, 2003; Warschauer, 2004; Hargittai in Waleyko, 2008). Pri razvrščanju različnih dejavnosti na spletu so ugotovili, da se nekateri ljudje ukvarjajo z majhnim številom preprostih in občasnih dejavnosti, drugim pa je splet tako rekoč že postal del njihovega življenja, kar ima zanje mnogotere koristi. V zvezi z vključenostjo spletnih orodij v življenje posameznika in načinom njihove uporabe je Marc Prensky (2001) skoval izraz »digitalni domačini/domorodci« (angl. digital natives). $\mathrm{S}$ tem poimenovanjem je želel poudariti, da so mlajše generacije »naravni govorci« digitalnega jezika računalnikov, videoiger in interneta. Tiste, ki niso bili rojeni v digitalni svet, vendar so ga na neki poznejši točki v življenju sprejeli in ga začeli uporabljati, pa avtor imenuje »digitalni priseljenci« (angl. digital immigrants). Digitalni priseljenci se sicer prilagodijo novemu okolju, vendar vedno do neke mere ohranijo svoj »naglas «, kot razlaga Prensky (2001). Tako denimo informacije sprejemajo in obdelujejo na način, kot so to počeli v preteklosti: besedilo, ki bi ga sicer lahko prebrali na računalniškem ekranu, si raje natisnejo; svetovni splet jim je torej sekundarni in ne primarni vir informacij. Starejše generacije uporabnikov interneta, ki so se »socializirale« na drugačen način kot njihovi otroci, so danes v procesu učenja novega jezi$\mathrm{ka}$ - jezika spletnih tehnologij.

In nekateri se v ta novi svet uspešneje socializirajo kot drugi. Hargittai in Walejko (2008) sta $\mathrm{v}$ svoji raziskavi o ustvarjalnih dejavnostih in izmenjavi med uporabniki interneta poskušala analizirati njihovo spletno udejstvovanje. Njune ugotovitve kažejo, da vse možnosti, ki jih uporabnikom interneta ponujajo spletne tehnologije in orodja, izkorišča razmeroma malo ljudi. Prav tako sta ugotovila, da se tako ustvarjanje kot posredovanje vsebin (»sharing «) povezujeta s socialno-ekonomskim statusom uporabnika, ki je bil izmerjen z izobrazbo njihovih staršev (prav tam). To še posebno velja za ustvarjanje vsebin, medtem ko je za izmenjavo in posredovanje vsebin med uporabniki interneta najpomembnejša razvitost spretnosti za uporabo tehnologije. Novejše raziskave o vplivu socialnega statusa na digitalno pismenost potrjujejo te ugotovitve (npr. Gui in Argentin, 2011).

To pomembno značilnost neenakosti uporabe interneta imenujejo tudi »neenakost udeležbe«. Nekatere študije namreč kažejo, da v večini spletnih skupnosti le manjši delež uporabnikov dejavno prispeva $\mathrm{k}$ vsebini spletnega mesta ali spletni skupnosti. Ta pojav ni značilen samo za uporabnike interneta $\mathrm{v}$ t. i. državah $\mathrm{v}$ razvoju, ampak tudi za tiste $v$ razvitih državah. Nielsen (2006) ga opisuje $\mathrm{z}$ razmerjem $» 90: 9: 1 \ll$, kjer je 90 odstotkov pasivnih uporabnikov, ki nikoli nič ne prispevajo, devet odstotkov uporabnikov prispeva malo, en odstotek pa prispeva večino vsebine ali komunikacije na neki spletni strani. Na spletni strani Wikipedija je recimo 77 tisoč aktivnih vlagateljev, več kot 17 milijonov registriranih uporabnikov in več kot 470 milijonov različnih obiskovalcev na mesec (podatek za februar 2012). To pomeni, da le majhen delež (približno 0,016 odstotka) obiskovalcev tega spletnega mesta dejavno prispeva $\mathrm{k}$ njegovi vsebini.

Ti podatki nam kažejo, da zgolj omogočanje dostopa do digitalnih tehnologij ni zagotovilo, da bodo uporabniki te tehnologije uporabljali smiselno in sebi v korist. V naslednjem poglavju bomo zato spoznali priložnosti, ki jih razvoj sodobnih spletnih tehnologij ponuja e- 
-učenju, pa tudi izzive, s katerimi se razvijalci tega učenja ob tem srečujejo.

\section{KAKŠNE SO PREDNOSTI IN PRILOŽNOSTI E-UČENIA ZA ODRASLE?}

Kadar ni ovir pri dostopu do interneta, ima e-učenje pomemben pozitiven vpliv na uspešnost, učinkovitost in prodornost izobraževanja odraslih. Njegova največja prednost je fleksibilnost, ki se nanaša na kraj, čas, hitrost, vsebino in metode učenja. Temeljni način podajanja e-učnih vsebin (ki so lahko v različnih medijskih formatih) je dostop do učnih enot $\mathrm{v}$ spletnih e-učilnicah. Orodja v e-učilnicah ponujajo učiteljem raznolike metode podajanja učne snovi, udeležencem izobraževanja pa paleto različnih dejavnosti - od študija e-učnih vsebin do izvajanja poskusov v virtualnih laboratorijih. Parcialne učne enote dajejo tako učiteljem kot tudi udeležencem priložnost, da z variiranjem učnih poti tvorijo različne učne celote in zaokrožene študijske vsebine. To je zelo ustrezno za učeče se odrasle, saj je lahko ista vsebina prilagojena različnim stopnjam predznanja udeležencev.

Kakovost e-izobraževanja za odrasle ni odvisna le od učne vsebine ali dejavnosti, temveč tudi od interakcije udeleženca $\mathrm{z}$ vsebinami, nalogami, mentorji in drugimi sodelujočimi. Vedno bolj široka uporaba tehnologij Spleta 2.0 (splet kot platforma za izmenjavo informacij, interoperabilnost, bogato uporabniško izkušnjo in predvsem sodelovanje) v izobraževalne namene prinaša pomembne spremembe v omenjene interakcije. Posledično so se pojavili novi didaktični koncepti, npr. t. i. sodelovalno učenje. Sodelovalno učenje lahko v prihodnosti pridobi posebno vlogo prav v izobraževanju odraslih, saj izrecno podpira ustvarjanje, sodelovanje in komunikacijo, če- sar pa so odrasli vešči bolj od mlajših učečih se. Izraz »sodelovalno učenje « (collaborative learning) si je zamislil Beckman (1990), vendar so možnosti takšnega načina učenja raziskovali tudi drugi: Collier (1980), Cooper (1990) ter Fiechtner in Davis (1992). Vsem raziskavam je skupno ukvarjanje $\mathrm{z}$ vprašanji učinkovite organizacije skupin, podpore skupinam, priprave navodil za delo $\mathrm{v}$ skupinah, pregledovanja skupinskega dela in načinov zagotavljanja pomoči članom, ki ne sodelujejo.

Sodelovanje v okolju družbenih medijev ni omejeno s prostorom, časom ali številom udeležencev. Katerakoli dejavnost med udeleženci s skupnimi cilji velja za sodelovanje. V iskanju uspešnega koncepta sodelovalnega učenja v okolju družbenih medijev Garrison in drugi (2000), Freire (2000) in Wells (1999) ugotavljajo, da je znotraj sodelovalnih učnih okolij zelo pomemben kritični diskurz med udeleženci. Rosen (2007) v svoji knjigi o kulturi sodeloNajvečja prednost e-učenja je fleksibilnost. vanja predlaga deset kulturnih elementov, ki podpirajo ustvarjanje vrednot: zaupanje, izmenjava, cilji, inovacije, okolje, nestrukturirana izmenjava idej, konstruktivno soočenje, komunikacija, skupnost in vrednote. Samo razvita osebnost, ki je sposobna kritične refleksije ter ima družabne in komunikacijske spretnosti, lahko ustvarjalno sodeluje - in prav zato je sodelovalno učenje še posebno primerno za izobraževanje odraslih.

\section{POVEČANJE DOSTOPA DO IZOBRAŽEVALNIH VIROV}

Ključna ovira za učeče se odrasle je dostop do visokokakovostnih učnih vsebin. S ciljem premagati to oviro je Unesco (2002) promoviral idejo »prosto dostopnih učnih virov« (angl. 
open educational resources). Izraz se nanaša na prosto dostopne elektronske učne vire, ki se lahko brez omejitev uporabijo in tudi nadgradijo (če so le uporabljeni neprofitno).

Zagotavljanje prosto dostopnih učnih virov je večplasten politični in družbeni izziv, saj ne ustvarja neposrednega dobička. Hylén (2006) opisuje pet razlogov za ponujanje prosto dostopnih učnih virov:

- izmenjava znanja je dobra sama po sebi,

- zvišanje vrednosti obstoječe naložbe javnega denarja,

- znižanje stroškov in izboljšanje kakovosti,

- pozitiven vpliv na odnose z javnostmi in

- možnost raziskovanja novih globalnih poslovnih modelov.

Gesser (2007) opredeljuje naslednje temeljne lastnosti prosto dostopnih učnih virov:

- Brezplačen dostop do vsebin (vključno z metapodatki) je na voljo izobraževalnim ustanovam in končnim uporabnikom, kot so učitelji, učenci in udeleženci vseživljenjskega učenja.

- Dovoljujejo se uporaba vsebine v izobraževalne namene, njeno prilagajanje, kombiniranje in ponovna uporaba. Zaradi lažje uporabe naj vsebine temeljijo na odprtih standardih in naj bodo $\mathrm{v}$ odprtih formatih.

- V e-vsebini so uporabljena programska orodja, za katera je na voljo izvorna koda. Na voljo so odprtokodni vmesniki za programiranje aplikacij in dovoljuje se ponovna uporaba spletnih storitev in virov.

Pedagoško-didaktični model je pri prosto dostopnih učnih virih nekoliko v ozadju. V razpravah pogosto prevladujejo tehnični vidiki in vidiki upravljanja, manj pa je opazen vidik izvajalcev in uporabnikov izobraževanja. Da bi v prihodnosti prišli do učinkovitega in razširjenega izobraževanja s prosto dostopnimi učnimi viri, je treba pri praktič- nih rešitvah celovito vključiti didaktiko in pedagogiko.

\section{SKLEP}

V uvodu smo omenili cilje Hamburške deklaracije, z njenimi izzivi pa se ubadamo še danes. Na nekaterih področjih je bil napredek očiten, recimo razvoj pismenosti odraslih, zmanjševanje razlik med spoloma, večja udeležba odraslih v izobraževanju, večja enakost in skrb za kakovost izobraževanja, kljub temu pa nekatere ovire ostajajo oz. se pojavljajo še nove - dostopnost e-izobraževanja in učenja na spletu je vsekakor ena izmed njih.

Strinjamo se lahko z Dukom in Hinznom (2011), ki menita, da moramo naše pojmovanje pismenosti razširiti na več kot samo branje, pisanje in računanje. Tem sposobnostim moramo dodati tudi spretnosti, ki so potrebne za učinkovito uporabo informacijske tehnologije (Duke in Hinzen, 2011: 21). Te kompetence so danes postale nujni pogoj za uspešno delovanje $\mathrm{v}$ zasebnem in poslovnem življenju.

Največja dolgoročna težava pa je dostop do interneta. Vse prednosti digitalnih tehnologij izzvenijo v prazno, če niso dostopne ljudem ali pa če ti nimajo razvitih veščin, potrebnih za njihovo uporabo. Podatki razkrivajo velike demografske in socialno-ekonomske razlike med državami na svetu. Na žalost za to težavo nimamo preproste in hitre rešitve. Chinn in Fairlie (2007) sta proučila 161 držav v obdobju od 1999 do 2001 in vpliv vrste gospodarskih, demografskih in infrastrukturnih dejavnikov. Ugotovila sta, da so se digitalne razlike znatno zmanjšale predvsem v državah, kjer so se odločili za javna vlaganja $\mathrm{v}$ človeški kapital, telekomunikacijsko in regulativno infrastrukturo. Ni dvoma, da bo to pomembna naloga strateškega razvoja Slovenije in drugih razvitih držav tudi v prihodnjih letih. 


\section{LITERATURA}

Beckman, M. (1990). Collaborative Learning: Preparation for the Workplace and Democracy. College Teaching, 4: 128-133.

Castells, M. (2002). The Internet Galaxy. Oxford: Oxford University Press.

Chinn, M. D., Fairlie, R. W. (2007). The determinants of the global digital divide: a cross-country analysis of computer and internet penetration. Oxford Economic Papers, 1: 16-44.

Collier, K. G. (1980). Peer-Group Learning in Higher Education: The Development of Higher-order Skills. Studies in Higher Education, 1: 5562.

Cooper, J. (1990). Cooperative Learning and College Teaching: Tips from the Trenches. Teaching Professor, 5: 1-2.

Duke, C., in Hinzen, H. (2011). Adult Education and Lifelong Learning Within. UNESCO: CONFINTEA, Education for All, and Beyond. Adult Learning, 4: 18-23.

Fiechtner, S. B., Davis, E. A. (1992). Why Some Groups Fail: A Survey of Students' Experiences with Learning Groups. V: Goodsell, A., Maher, M., Tinto, V., in drugi (ur.), Collaborative Learning: A Sourcebook for Higher Education. University Park.

Freire, P. (2000). Pedagogy of the oppressed. New York: Continuum.

Garrison, D. R., Anderson, T., in Archer, W. (2000). Critical inquiry in a text-based environment: Computer conferencing in higher education. The Internet and Higher Education, 2-3: 1-19.

Gesser, G. (ur.) (2007). Open Educational Practices and Resources. Salzburg: Open e-Learning Content Observatory Services.

Gui, M., Argentin, G. (2011). Digital skills of internet natives: Different forms of digital literacy in a random sample of northern Italian high school students. New Media \& Society, 6: 963-980.

Hargittai, E., Walejko, G. (2008). The Participation Divide: Content creation and sharing in the digital age. Information, Community and Society, 2: 239-256. Dostopno na: http://www.
webuse.org/pdf/HargittaiWalejko-ParticipationDivide2008.pdf.

Hayes, E. (2007). Reconceptualizing Adult Basic Education and the Digital Divide. V: Belzer, A. (ur.), Toward Defining and Improving Quality in Adult Basic Education: Issues and Challenges. New York.

Hylén, J. (2006). Open Educational Resources: Opportunities and Challenges. Dostopno 17. 7. 2012 na: http://www.oecd.org/dataoecd/5/47/37351085.pdf.

Internet World Stats (31. december 2011). Dostopno na: http://www.internetworldstats.com/stats.htm.

International Telecommunication Union (2011). The World in 2011: ICT Facts and Figures. Dostopno na: http://www.itu.int/ITU-D/ict/facts/2011/index. html ali http://www.itu.int/ITU-D/ict/facts/2011/ material/ICTFactsFigures2011.pdf.

Mossberger, K., Tolbert, C. J., Stansbury, M. (2003). Virtual inequality: Beyond the digital divide. Washington: Georgetown University Press.

Nielsen, J. (2006). Participation inequality: Encouraging more users to contribute. Dostopno 17. 7. 2012 na: http://www.useit.com/alertbox/participation_inequality.html.

OECD (2001). Understanding the Digital Divide. OECD Digital Economy Papers, No. 49, OECD Publishing. Dostopno na: http://dx.doi. org/10.1787/236405667766.

Prensky, M. (2001). Digital Natives, Digital Immigrants. Lincoln: NCB University Press.

Rosen, E. (2007). The Culture of Collaboration: Maximizing Time, Talent and Tools to Create Value in the Global Economy. San Francisco: Red Ape Publishing.

International Telecommunication Union (2011). The World in 2011: ICT Facts and Figures (2011). Dostopno 7. 8. 2012 na: http://www.itu.int/ITU-D/ ict/facts/2011/index.html.

UNESCO (1997). CONFINTEA V: The Hamburg Declaration and Agenda for the Future. Hamburg: UNESCO Institute for Lifelong Learning. Dostopno 17. 7. na: http://www.unesco.org/education/ uie/confintea/. 
UNESCO (2002). Globalization and Higher Education. The First Global Forum on International Quality Assurance, Accreditation and the Recognition of Qualifications in Higher Education. Paris: UNESCO.

UNESCO (2009). CONFINTEA VI: The Belém Framework for Action: Living \& Learning for a Viable Future: The Power of Adult Learning. Hamburg: UNESCO Institute for Lifelong Learning. Dostopno 11. 7. 2012 na: http://www.unesco. org/en/confinteavi.

Van Dijk, J. A. G. M. (2005). The deepening divide: Inequality in the information society. Thousand Oaks: Sage.

Van Dijk, J. A. G. M. (2006). Digital divide research, achievements and shortcomings. Poetics, 4-5: 221-235.

Van Dijk, J. A. G. M., Hacker, L. K. (2003). The digital divide as a complex and dynamic phenomenon. The Information Society, 4: 315-326.

Warschauer, M. (2004). Technology and social inclusion: Rethinking the digital divide. Massachusetts: The MIT Press.

Wells, G. (1999). Dialogic Inquiry. Cambridge: Cambridge University Press. 